\title{
Ecclesiola in ecclesia in Brazil from a missio Dei perspective: An autoethnographic case study of four Presbyterian churches in Brazil
}

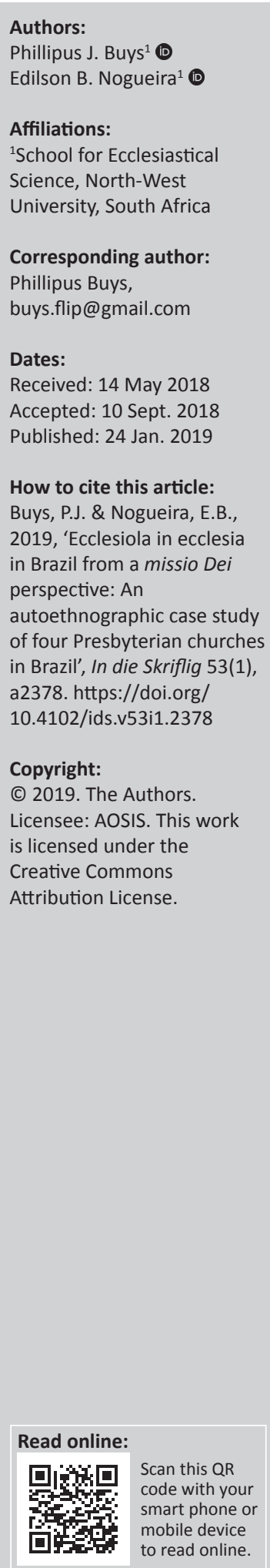

This study represents an unconventional qualitative research genre, autoethnography, which is not commonly found in qualitative research circles, and is rarely used by researchers in South African and Brazilian social science. The main question behind this research is: Why were some Presbyterian churches in Brazil challenged by a significant loss of members while others were experiencing 'times of refreshing' (Ac 3:20)? There are even statistics of extraordinary increase in the participation, interest in and outreach to their communities of some churches. The question why some churches belonging to the same denomination, in the same city and presbytery and with some liturgical likeness, for some reason, were growing while others were shrinking, became a driving question leading to this research. Four growing Presbyterian churches were chosen because all four were using small group ministries. They were situated in four different cities, one in the northern part of Brazil, three in the southwest, and they were using the same method, with their own adaptations. Each of them experienced gracious growth within their own context. Through their ministries, ordinary people were doing ordinary things with extraordinary results of radiating the universal priesthood of all believers, exercising a missional witness and reaching out to a world in need. This article aims to consider their motivation, the challenges they experienced during the implementation of small group ministries, the positive and negative aspects of the process, the lessons learnt and possible application for the revitalisation of Igreja Presbiteriana do Brasil (IPB) today.

\section{Introduction}

\section{A brief definition of autoethnography}

This article was written partly according to autoethnographic qualitative research methodology. According to Elis and Bochner (2000:733), autoethnography is a way to understand a certain culture or a group of people through the eyes and perspective of a researcher who is personally involved with the objects of the research. The article is partly based on personal experience, observation and reflection and partly on the responses of the senior pastors of four Presbyterian churches, on a questionnaire sent to them, of which the answers, sent back by email, are in my possession. I (Edilson B. Nogueira - further referred to as EBN) was personally deeply involved with one of the churches as its pastor for several years and thus gained many insights on the issues that are addressed in this research. I also had personal talks with the senior pastors of the other churches on several occasions to which I refer in this article. The purpose of the article is to identify, through the practices of those churches, their values and principles that support their beliefs (Elis 2011:275276) and the theological fundamentals for church growth as it was experienced by the four churches referred to in this article. Some personal stories are told to demonstrate that real persons were changed by a life in fellowship in small group ministry that was introduced in their churches.

\section{Background: General challenges of Christianity in Brazil}

Since the beginning of the 21st century, the relevance of the church and its message have been under scrutiny in many places around the world, also in Brazil. Tim Keller (2012:11-13) in his Center church, considers three basic perspectives that are generally seen as aspects of relevant churches: success, faithfulness and fruitfulness. He points out that many people measure success by a large audience, a charismatic preacher, a huge building, a contemporaneous music style, and the extensive use of the media. Faithfulness refers to a church that maintains its tradition and doctrinal roots, orthodox preaching and liturgy. Fruitfulness is a local church's effectiveness in their ministry and service to the community in its context. A church can be orthodox in its message 
and liturgy but may be irrelevant, with little or no influence in the city where it is situated or can be lacking the fruit of reaching unbelievers and outsiders, despite her doctrinal purity. A church can also be successful in bringing large crowds to the services, using all kinds of modern marketing strategies, but be compromising the biblical truth and congregational ministry structures that are conducive for new believers to grow in grace and knowledge of the Lord Jesus Christ (2 Pt 3:18) and no real discipling of new believers is happening.

Besides that, there is an emergence of a non-religious population in Brazil (more than 15 million according to the Brazilian Institute of Geography and Statistics - IBGE Census 2010), a growing generation not interested in church or disappointed with religion, which can partially explain the decline in membership and influence of the historical denominations. The Roman Catholic Church, according to the census of 2010, lost 1.7 million of its members, a decline of 12.2\%; the Evangelical Lutheran Church declined from 1062144 to 999498 (-5.9\%); the Evangelical Congregational Church from 148840 to 109 591. In his analysis of the census, Mariano (2013:119-137) concludes that although the historical protestant churches (mission churches) grew 10.8\%, it is far less than the figure of $58.1 \%$ which occurred in the previous decade. The Pentecostals grew only $44.0 \%$, which is not even half of their numerical growth during the previous two decades as they were 8.8 million in 1991 (111.7\% increase) and 17.7 million in $2000(+115,4.0 \%)$. How should reformed churches face this complex scenario and provide answers? How can they become relevant in a context of indifference to religion and at the same time, preach to people overexposed to a gospel culture as in the television shows of the neopentecostal churches?

\section{Seemingly decline of Iglesia Presbiteriana do Brasil churches}

The IPB is facing her hardest challenge in history: stagnation and decline in membership. The Census of 2000 by the Brazilian Institute of Geography and Statistics (IBGE) indicated a membership of 981064 Presbyterians, but the census of 2010 indicates that only 921209 people identified themselves as Presbyterians, revealing a decline in the region of 60000 members in 10 years' time. In a 2016 research, based on the available data at the General Office of the IPB, it is estimated that there are around 820000 members, although this number may not reflect reality because of a lack of information from some congregations. There are 4650 pastors, 1450 missionaries, 820 evangelists, 83 synods, 335 presbyteries and 6373 communities (churches and congregations). The Centro Presbiteriano de Pós-Graduação Andrew Jumper (CPAJ) now offers a postgraduate qualification in the 'Revitalisation and Multiplication of Churches', and some reasons why this study program is offered can be found on the website of CPAJ (Centro Presbiteriano de Pós-Graduação Andrew Jumper, 2018):

... secularization, loss of excellence in preaching and organic life, the absence of new believers (new converts) and the loss of relevance to respond to genuine questions of our time through the Scriptures, are signs of an illness of a church location or a region and also of pastoral ministries.

Statement reveals that the IPB is not immune to the decline that is now happening in several denominations in Brazil.

\section{Need for general revitalisation and strengthening of missional outreach}

\section{A working definition of revitalisation}

The Oxford Dictionary explains the word revitalisation as to re-energise, to renew, to restore, to revive, to refresh, to breathe a new life into, reawaken, to resuscitate, giving the idea of a new beginning. The Lord Jesus said: 'I have come that they may have life and have it to the full' (Jn 10:10). The church ought to be a place of life, abundant life, eternal life, meaningful life, and this is the reason why the revitalisation of the church is deeply necessary - it is a matter of essence, of nature, of purpose. The church is an assembly of sinners, forgiven by the blood of Jesus, but still fighting against a sinful nature which indwells in the believers. Therefore, the battle for sanctification is sometimes lost, and then stagnation and corruption take the body of Christ.

Buys (2012) lists the following signs of stagnation of churches: firstly, a lack of biblically based assurance of salvation, when believers say they are Christians but have no assurance of salvation in their hearts as it is written in Romans 8:16; secondly, sacramentalism and formalism are when the church members think that by being baptised and to participate in the holy supper monthly, may entitle them to be confident. As Martin (1980) formulated:

If I am only in the right place, at the right time, doing the right thing, in the right way, in the presence of the right man, then I must be right with God. (quoted by Buys 2012)

Thirdly, a lack of evangelistic zeal and missional power, which is a clear sign of the lukewarmness of the church, when nobody cares for the unreached; fourthly, the lack of discipline in the church, when believers show no difference in their moral lives with the unbelievers, practicing all kinds of deviation without any sense of guilt, turning the witness of the church needless; fifthly, ineffectual preaching, when the exposition of the Scripture is changed to mere motivational speeches, philosophical discourses and merely a goal to make the audience feel good. All these signs can be found in many reformed and Presbyterian churches in Brazil, as well as in South Africa. Revitalisation is the ministry of the Holy Spirit. As iniquity and corruption in the church grieves the Holy Spirit, humility and repentance brings renewal, but only through the agency of the Lord - 'for it is God who works in you to will and to act in order to fulfill his good purpose' (Phlp 2:13). This operation of the Holy Spirit is explained in the Canons of Dordt, in the fourth Chapter, article 7:

... by his Word and Spirit He certainly and effectively renews them to repentance so that they have a heartfelt and godly sorrow for the sins they have committed; seek and obtain, through faith and with a contrite heart, forgiveness in the blood 
of the Mediator; experience again the grace of a reconciled God; through faith adore his mercies; and from then on more eagerly work out their own salvation with fear and trembling.

God restores his church from lukewarmness to a fervent Christian faith, through genuine repentance, deep sadness and contrition, that moves the believer to run to the throne of grace. Van 't Spijker quoted Calvin (as quoted and translated from Dutch by Buys 2012) by saying:

When the church doesn't shine as a light we oftentimes think that it has been quenched completely and has perished. But in this way (by successive resurrections) God preserves his church from the world ... the church does not live without resurrection, yes not even without many resurrections, so to speak.

Accordingly, through these successive resurrections, the church of Christ not only survives but also becomes missional and active in the world. As Buys (2012) concludes:

\begin{abstract}
... revitalization is a combination of Holy Spirit lead reformation and revival that constitutes renewal of heart, mind and will of church leaders and church members and invigorate them with new vision and passion to worship the Triune God, proclaim his grace and judgment and be his instruments of true compassion in the world.
\end{abstract}

As a living organism, the members of the church who have been revitalised in heart, mind and will, become living witnesses, true worshippers, and servants to reach the nations of the world as well as the lost and backslided Christians in their nearby context.

\section{Information asked from four Presbyterian churches}

Amazingly, some local Presbyterian churches in Brazil in different parts of the country seem to have overcome this challenge, experiencing effective revitalisation of their church and ministry, experience significant numerical growth, a notable Christian impact in the city, effective outreach to nonbelievers and unchurched people and embracing a missional practice of planting several new daughter churches, resulting from the work of the Holy Spirit. Clear examples are the Presbyterian Church of Manaus in the State of Amazon, in the northwest part of Brazil, the First Independent Presbyterian Church of Londrina, the Independent Presbyterian Church of Maringá, both in the State of Paraná, and the Presbyterian Church of Macaé, in the State of Rio de Janeiro, where I (EBN) was the pastor from 2008 to 2015. How should the revitalisation of these churches be understood, explained and assessed? How did these churches reverse the declining trend? What have I experienced and what insights have I gained as pastor of the church of Macaé? What do these churches have in common, although they are in different regions of Brazil? Have they remained faithful to biblical standards of the reformed ecclesiology?

This article was guided by Smith's perspective (2016) of a descriptive research as a useful ministry tool to reveal a truthful reality where the researcher can understand the challenges and the possible answers to the problems. The qualitative data comes from responses on questionnaires sent to the current pastors of four Presbyterian churches, and my personal observations and experiences, to come to a final analysis of the scenario.

The questionnaires are sent to the senior pastor of each one of these churches. They agreed to answer the questionnaire to help me in writing this article, and in doing so to be an inspiration to other Presbyterian communities in Brazil and around the world. The questionnaire had the following questions:

1. How many members do you have in your church?

2. What factors were decisive for the implementation of small group ministry in your church?

3. What problems and challenges convinced you to consider the implementation of small group ministry in your church?

4. When did you start to implement small group ministry in your church?

5. What was the purpose of your church to develop the implementation of small group ministry in your church?

6. What role does the senior pastor and elders play in the small group ministry in your church?

7. What are the difficulties you faced during the implementation of small group ministry in your church?

8. What results (positive and negative) did your church experience from the implementation of small group ministry?

9. What lessons have you learnt from applying small group ministry in your church today?

All the questions were carefully answered by these pastors and their opinions were very respected to compose this article, each one giving an honest view of their communities, not hiding the failures and difficulties during the process to establish small group ministry.

\section{Profile of four churches}

Four Presbyterian churches were analysed for this study: Macaé, Maringá, Londrina and Manaus. In the four cities, these churches were the first Presbyterian churches planted in each city, which give them an important role as mother churches.

\section{Presbyterian Church of Macaé, State of Rio de Janeiro}

This church was planted in the first half of the 20th century by some Presbyterian ministers who lived in the mountainous region of Rio de Janeiro, in the city of Friburgo. They used to go down the hills to the seaside to hold services in small houses in the city of Macaé. Years later in 1957, the small congregation became an organised church. The city of Macaé is located at the coast of the State of Rio de Janeiro, circa $170 \mathrm{~km}$ from the capital, and is known as the 'national oil capital', for the general office of Petrobras, the state company of oil, is located there. Macaé has more than 
240000 inhabitants (IBGE), and before the crisis of 2016 when a scheme of corruption was uncovered by the federal police, around 500 companies from 50 different countries were located there, working for Petrobras. With the crash of Petrobras, thousands of jobs were lost, people left the city, stores were closed, the commerce was severely effected and all churches of the region suffered a decline in their budget. The Presbyterian Church of Macaé, where I was the pastor from 2008 to 2015, has grown to 637 members with 34 small groups by the end of 2015 .

\section{Independent Presbyterian Church of Maringá, State of Paraná}

The Independent Presbyterian Church of Maringá, according to Waldemar de Souza, the senior pastor, was founded in 1949, only 2 years after the founding of the city of Maringá. The city is located in the State of Paraná, with more than 400000 inhabitants, and the church belongs to the Independent Presbyterian Church of Brazil (IPIB). This denomination was founded in 1903 by the Rev. Eduardo Carlos Pereira, after a disagreement about the incompatibility between Masonry and the gospel, during a meeting of the Presbyterian Synod on 31 July 1903 (LESSA 1938). Today, after a decision taken in the General Assembly of IPB in 2010 (resolution LXXVII, SC/IPB 2010) in both churches, IPB and IPIB, Masonry is considered not compatible with the evangelical profession. The IPB of Maringá has 2328 members and adopted a practice of small group ministries in 1997, after a careful study of the method proposed by Ralph Neighbour Jr., founder of Touch Outreach Ministries-USA.

\section{Independent Presbyterian Church of Londrina, State of Paraná}

The First Independent Presbyterian Church of Londrina, began in the first half of the 20th century when some migrant families of farmers came from the inland of the State of São Paulo, having the first services in a very rustic house. They were instituted as a church in 1938 with 120 members. Today the IPI of Londrina has 5275 members, two places of worship and has 246 small groups meeting weekly around the city. Londrina has more than 550000 inhabitants.

\section{Presbyterian Church of Manaus, State of Amazonas}

The Presbyterian Church of Manaus founded in 1904, and the oldest of the four churches, is today the largest Brazilian Presbyterian church with an estimated membership of 9000 in the city and nearby congregations. I spent my boyhood in this church, where my father was the pastor from 1960 to 1972, and I feel a special gratification to write about this community. According to José João Mesquita, the current senior pastor, the church council decided in 1998 that the IPM should become a cell church and it also adopted the model created by Ralph Neighbour Jr. Today there are 428 small groups meeting weekly in the city of Manaus and in smaller communities on the banks of the Rio Negro and Rio Amazonas.

\section{Motives for implementing a small group ministry}

At the end of 1997 Dr Ralph Neighbour Jr. (1992; 2000; 2008) came to Curitiba, capital of the State of Paraná, to share his cell church vision as a second reformation in the reformed church through the principle of the practice of the priesthood of all believers. I was there together with the pastors of the churches of Manaus, Londrina and Maringa, aiming to learn more about this ministry of small groups. In our hearts, we all wanted to do better pastoral ministry and see the church growing to expand the kingdom of God in the cities where God had placed us. It was a surprise to learn from Ralph Neighbour that revitalisation was not just about what we could do, but also how to teach church members to do ministry. He focused on the laity - the principle of the priesthood of all believers.

The church of Macaé already had small group meetings every week, but not all the members of the church were attending and there was no connection between the ecclesia and ecclesiola.

My motivation was to bring the majority members to a deeper experience of fellowship within the body of Christ. This seemed to be a major issue for all four churches: to strengthen the unity of the Spirit living in the church.

For the church of Maringá, there was a perception that all the events and special programmes were not meeting the spiritual needs of their members. Members admitted a lack of passion for evangelism - a kind of accommodation to the situation. The church of Londrina was striving to assimilate new members into a deeper communion with all members in the church, in light of the danger of loneliness in the huge multitude of people in the church. The church of Manaus wanted a biblical and theological system that allowed them to nurture and disciple the members in the city, as well as the dozens of small congregations of ribeirinhos [those who live on the banks of Rio Negro and Rio Amazonas]. In summary, we all longed for a revitalisation of the relevance of the church in all dimensions of biblical ecclesiology.

\section{Methods followed to implement a system of small group ministry}

The four churches decided to use Ralph Neighbour Jr.'s method, viz. the Cell Church Ministry, but contextualise it to the fit into the Brazilian and Presbyterian context. Basically, the senior pastor, after attending four modules of training, began a prototype cell with key leaders. The goal was to provide opportunities for them to experience all the processes and practices that an ordinary small group had to go through, including means to apply the Word, pray for each other, evangelise, disciple new converts, and at the same time prepare a leader for a new cell. After a while with these lay people, the small groups were opened for all the members to attend under the supervision of the pastor. Each small group had a leader and two interns who would be trained to be the 
leaders of the next generation of the cells. The agenda of the meeting was the following: a welcome to the participants, an introduction to each other, a brief icebreaking, a praising time, a prayer time, application of the Word (generally about the principles outlined in the previous Sunday's sermon), a time to pray for each other, and finally together as the group, pray for their relatives and friends to come to Christ. During the existence of the small group, there were some training meetings for evangelism, inner healing and discipleship, among others, to nurture the Christian faith and maturity of the members.

There were several other methods of small group ministry in Brazil. The best known are the Apostolic Discipleship Model (Modelo de Discipulado Apóstólico - MDA), founded by Aber Huber of Igreja da Paz in Santarém, state of Pará (Huber 2012a; 2012b; 2016) and the G12 model founded by Cesar Castellanos (Castellanos 2002; 2013; 2015), pastor of Mission Carismática Internalcional in Colombia.

Reformed and Presbyterian churches did not find these to be in line with reformed ecclesiology. In the majority Pentecostal and charismatic churches, any lay leader may administer the sacraments of baptism and holy communion, while in the reformed and Presbyterian churches this is an exclusive pastoral office. In these models, some traditional structures are easily and quickly discarded. This is the reason why it is so important for Presbyterian churches to establish clear principles to guide the local congregations in small group ministries.

\section{Challenges faced in implementation and solutions applied}

The four churches faced different challenges while they were implementing small group ministries.

The IPI of Londrina, for example had to work carefully to establish a new mentality - from the centrality of the pastoral ministry to a lay ministry. This church had great preachers and blessed ministers in her history and one can imagine that it was not an easy task to change the way of thinking from the pastor doing everything to the 'we are responsible for the mission' mentality.

The IPI of Maringá also struggled with a change of mentality as the council and the pastor taught the principle of the priesthood of all believers, but also faced resistance from a part of the membership to be members of small groups.

The IPB of Manaus faced a peculiar difficulty - a concern of a relevant part of the membership that the small group ministry would not end the traditional structures and departments of the IPB such as SAF (Sociedade Auxiliadora Feminina, women society) and UPH (União Presbiteriana de Homens, men society). In a very wise strategy the council of the church of Manaus kept the structure, but implanted a missional mentality, and now it is the largest Presbyterian church in Brazil.
In the case of IPB of Macaé, where I worked from 2008 to 2015, the small group ministry was already initiated by a colleague, Rev. Elson Moraes, who was the senior pastor for 21 years. When I came in 2008 we decided to call all the leaders of the existent groups, who at the time were the elders of the church, to spend some months learning the principles of the new methodology. In this church there were no problems with the implementation of the cell church methodology, because they already had a culture of functioning in small groups. The first problems began when some persons showed resistance to move to another group with new members, as necessitated by growth. We handled this challenge by teaching the one another principle. Yes, one of the benefits of living together in community in a small group, is the sense of belonging to a family. The feeling of familiarity and intimacy grows as the time goes by, and it is not normal to expect members ardently to loose it. But, an argument used to open their mind and raise compassion for unbelievers came from the four leprosies in 2 Kings 7:9:

Then they said to each other, 'What we're doing is not right. This is a day of good news and we are keeping it to ourselves. If we wait until daylight, punishment will overtake us. Let's go at once and report this to the royal palace.'

Staying together is likeable, enjoyable, but could diminish the extension of the Tent, while the missional moto of the church of Macaé was - 'preaching until the last one of the earth be reached'. After teaching this for a while we had no more resistance for they understood it was necessary for the benefit of the unreached. When members develop a missional vision and passion for the local church they become willing to accept changes and make sacrifices for the sake of reaching non-believers and assimilate them into the church when they are new believers.

The different challenges that the four churches faced, indicated the need for revitalisation and the application of the priesthood of all believer principle in our communities as well as a deeper missional commitment.

\section{Positive and negative results}

After 17 years persevering with the small group ministry, these churches reviewed the results of the method.

At the IPI of Londrina, according to Rev. Mathias Quintela the former senior pastor who still works in the church, small groups became the basic ministry stucture of the church, providing fellowship, evangelisation, accountability, discipleship, prayer, and mainly the capacity of the members to serve with their spiritual gifts in the context of the cell. As a consequence they created a support system for the small groups by offering courses and seminars to improve the Christian education, musical formation through a school, children's ministry, teenager ministry, youth ministry, couple's ministry, women and business men ministry.

According to Rev. Valdemar de Souza, senior pastor, a positive result was an increase in the membership of the IPI 
of Maringa, as it grew from 400 members in 2000 to 2328 in 2017 - an increase of almost 500\%. They observed a growing interest of the members to attend the small groups, and to become leaders. As a result, this church established a special ministry for training and preparation for new leadership, namely the Christian Formation Academy, which offers several courses to equip the members of the church involved with the cells.

The IPB of Manaus, through their senior pastor, the Rev. J.J. Mesquita, admitted that they had problems during the implementation of the program, due to their inexperience with small group ministry, and eventually several cells had to be closed. But they overcame this challenge, by improving the training and formation of leaders. Today, after 22 years of persevering with this ministry, the church has become the largest Presbyterian church in the country, growing from 1000 members in 1995 to circa 9000 in 2016. This church has a vision to reach the ribeirinhos, and to build Medical Boats to visit the communities of the inner Amazon, bringing medical aid and the preaching of the gospel.

In the IPB of Macaé, the smallest of the four churches, two goals were achieved in the weekly meetings of the small groups: the spiritual nourishment of the body of Christ and the training of new leaders, since some parts of the meeting were conducted by them under the supervision of a more experienced leader. Once a month, each small group had a special meeting to which they invited their friends from work, relatives and neighbours to join them. Pizzas, hamburgers or barbeque were served, and before they finish a member of the group would give a testimony of how he or she had met Jesus as the Lord and Saviour. Visitors were invited to come and participate in the next cell meeting. Many of those friends began to show interest in the gospel after these meetings, and after a while they confessed Christ as their Saviour and joined the community. Every second month, each group was also challenged to pray for a need in its region. This activity was called the 'Taking the hand of Christ to the streets'. The hand of Christ is a prayer time in the weekly meeting when the group intercedes for the need of those who are present. The purpose was to meet a need in the neighbourhood and share the love of Christ. Some groups got up early in the morning, took hot coffee and chocolate to offer to those who were waiting in line to see the doctor in a public clinic. While they were drinking the coffee, a member of the group asked why they were there and then prayed for their needs of that day. Some visited nursing homes, some went to squares and prayed for the needs of the passers-by, some went to hospitals to pray for the sick, some took toys and organised a playroom for hospital children. One group had the idea of getting some doctors together and going to a poor community of the city, inviting the parents to bring the children to be treated by a doctor, after which they talked and prayed for them. During the last 8 years, the Presbyterian Church of Macaé added more than 480 people to her membership through the small group ministry. They had 34 groups, each group with a leader and one in training. We also had several kinds of groups - groups for newly wedded couples, youth, teenagers and the elderly members.

Therefore, with this ministry we could achieve three objectives: nourishing the Christian faith and strengthening the fellowship of the church members in the weekly meetings, training new leaders on Sundays, and evangelising the neighbours, friends and family of those who were part of the cell group.

\section{Lessons learnt}

Considering that the four churches began at almost the same time with the implementation of small group ministries, with the same method but contextualising it according to their own environment, there is consensus among us about the value of this ministry.

Firstly, the four churches were moved toward small group ministry by the same motivation, namely how to deepen the relationship of the community and provide pastoral care. There is no doubt that the biblical principle of koinonia and the church as a body of Christ in all its richness can be effectively achieved in a small group ministry. People with different backgrounds, different values, different senses of humour, different viewpoints, different personalities, come to the small group meetings, but under the cross, under the unity of the Spirit, and under the grace of God, they can enrich each other's lives by supporting each other. Of course, there are discussions, disagreements, and sometimes broken relationships; however, as members of the body of Christ, there is an opportunity to open the hearts to forgive and try again to live in harmony. Because of this, the pastoral care becomes a communal ministry. As in a natural family, the oldest brothers take care of the younger ones. My personal experience was that, most of the ordinary problems can be solved by dedication of time to hear a compassionate prayer, a phone call, or even the gift of the presence - simple things that the members of a small group can offer each other. In this way, the pastoral ministry can be freed to attend to more serious problems of the community. It has happened often when visiting someone in the hospital to hear the patient say: 'Pastor, how good it is to see you, but the people of my group already came to see me...'.

Another positive aspect of the experience of the four churches is the restoration of the value of friendship as a bridge to reach relatives, neighbours and friends who are not Christians or members of churches, with the message of the gospel. The number one complaint of non-Christians about their newChristian friends is: 'They don't care for us anymore.' An incident that confirms the need for friendship evangelism that occurred in the Presbyterian Church in Campinas, state of São Paulo, Shalom church: We decided to spend a Sunday morning and evening once a month with our friends and neighbours. We temporary suspended the Sunday school, moving the classes to Saturdays. One of our elders told us the following: He left his house with his two little boys wearing a short and a t-shirt, for a walk around the block. As soon as 
they got out of the house, one of his neighbours, surprised to see him not in his suit and tie as usual, and driving to the church, cried:

Marcelo, my dear friend, what are you doing here? You didn't go to the church today? Hey, why don't you come to my house, let's have a 'churrasco' [barbecue], we can have all day long together.

Marcelo and his neighbour spent the whole day talking and developed a friendship relationship. This experience, temporarily of course, gave to our members an opportunity to appreciate and realise the importance of making friends, and through this, to lead such friends to Christ.

\section{Reflection}

\section{Congruence or divergence with the main principles of reformational ecclesiology?}

How are the ministry models of the four churches in line the basic reformational ecclesiology?

During the 16th and 17th centuries some attempts to use small group ministry as an instrument to revitalise the church were done by the leaders of the Reformation in the 16th century and in Post-Reformation by Zinzendorf at the Herrnhut and John Wesley with the Methodist societies.

Luther, in the preface of his German Mass, proposed the formation of conventicles, small groups meeting in a house 'to pray, to read, to baptize and to receive the sacrament and practice other Christian works'. And Luther (quoted in Kidd 2004) concludes:

Here there would not be need of much fine singing. Here we could have baptism and the sacrament in short and simple fashion: and direct everything towards the Word and prayer and love. Here we should have a good short Catechism about the Creed, the Ten Commandments, and the Lord's Prayer. (p. 196)

Unfortunately, Luther could never fully implement his intent because he said:
... if we only had people who longed to be Christians in earnest.
... But I cannot and would not order or arrange such a community
or congregation at present. I have not the requisite persons for it, nor do I see many who are urgent for it. (p. 196)

Martin Bucer, a contemporary of Luther, realised that justification received by faith, needed to be lived out through sanctification. Small groups were a pragmatic way to work out sanctification. This was written in 1538 when Martin Bucer was at the height of his leadership in the Reformation of Strassbourg. Bucer's main book, Concerning the true care of souls, offered biblical insight into the pastoral work of leadership, shepherding, and discipline in the church. Bucer clearly had a deep pastoral motivation in his practical implementation of small group ministries (Barr 216:103).

Bucer (2009:112-113) believed in a fivefold dimension of the pastoral ministry: firstly, to call to the church communion those who are outside of it due to sin or false doctrine; secondly, to restore the faith of those who became deviant of the Christian faith; thirdly, to call to repent those Christians who were having a sinful life; fourthly, to strengthen the weak in faith; fifthly, to instruct the believer that he may not fall in false teachings. But how does one reach these dimensions in a practical way? For Bucer, the New Testament church's lifestyle was both inspiration and prescription, and his favourite passage was Acts 2:46 where the agenda of the community was established:

Every day they continued to meet together in the temple courts. They broke bread in their homes and ate together with glad and sincere hearts, praising God and enjoying the favor of all the people ...

For this purpose, he founded ecclesiola in ecclesia: small groups meeting at homes under a doctrinal covenant and Scriptural submission.

\section{Comiskey (2000) summarises:}

Bucer was the first true forerunner of cell-based ministry because he desired to connect the gathered church with the scattered church. It was not a matter of deciding to support the inclusive state church or the church gathered in homes. Rather, he felt the need for both. (pp. 1084-1085)

Bucer became increasingly drawn to the model of the primitive church which emphasised both large and small groups.

Researchers who have done intensive studies of the ministry structures in the Early Church, provided clear evidence that the Early Church in the first three centuries AD functioned through small gatherings, mostly in the houses of believers. In an in-depth study with a floodgate of references to prove his findings, Vogler (1982:786-794) stated: '... dürfte unbestritten sein, dass diese Gemeinden Hausgemeinden waren. Denn zu dieser Zeit gab es noch keine kirchlichen Räume oder Gebäude'.

It is indeed true that there is no evidence of any church buildings before AD 300 (Banks 1980:41). Vogler refers to the research of Schlatter and Stuhlmacher who pointed out that religious gatherings in houses of believers actually became a widespread practice since the exile of Israel and that there were many 'house synagogues' in the times of the New Testament.

Bucer established small groups in Strasbourg to revitalise the unity, purity, catholicity and apostolicity of the church. He implemented a system of Gemeinshaften. Firstly, pastors should preach about the biblical principle of community and how they ought to live in community. Then the pastor should meet at the home of a certain parishioner emphasising the nature and characteristics of a true Christian community, and make sure that they fully understand the principles. After this, the group had to elect one or two leaders who would work together with the pastor and the Kirchenpfleger [ward], and constitute a board of the group. Every part of the Gemeinshaften had responsibilities: the pastor should maintain the purity of the doctrine; the elders should live in integrity 
and be faithful to the doctrine; the membership should live a godly life, expressing a sincere repentance, and the full understanding of the sacraments, only to be administered to people after they have been registered in the Christliche Gemainshaft. In summary, Bucer worked with a simple formula: unity brings strength in the temple and in the home, established godly lives for authentic witness, and solid doctrine made apostolicity real (Wright 1994:129-143).

However, because of the conviction that only the Senate-andXXI, a civil council, could discipline a church member, ecclesiastical discipline administered by small groups was fiercely questioned by city counsellors and taken as an abuse of the authorities of the city. It was considered an innovation to the church order (Kirchenordnung), which was strictly forbidden since 1534, and eventually, the small groups died in Strasbourg after Bucer was expelled from the city in April 1549.

Bucer boldly admonished the city council of Strasbourg in 1549 when they agreed to sign the Augsburg Interim (15 May 1548) after the Schmalkaldic War (1546-1547) of the risk to provoke the wrath of God which could bring the destruction of the whole city. In the Methodist societies, Wesley tolerated doctrinal divergences, but he did not hesitate to exclude members whose lives did not fit the gospel patterns. Those who cursed, lied, sold liquor, broke the Sabbath, were drunk, spanked a wife, or even those who lived a careless life, were excluded to preserve the testimony of the Christian faith (Snyder 1996). In the 21st century, especially in Brazil due to a worldly mentality of some Christian members of the church, the practicing of church discipline has become difficult. In Strasbourg it was also not an easy task to apply church discipline. Some members of the city council became so upset with the practice of church discipline that they expelled Bucer from Strasburg.

This raises the question to what extent Christian discipline can function in small group ministry in current day Presbyterian churches. In the 21st century, especially in Brazil due to a worldly mentality of some Christian members of the church, the practicing of church discipline became difficult.

Buys (2013), in his lecture at Mukhanyo Theological College says:

According to the teaching of Christ, in Mathew 18.15, where does church discipline start? Jesus says it starts with one believer that has become acquainted with the sins of a fellow believer and who goes and talks to him alone in love and wins him over to Christ and the paths of righteousness. It is important to remember that this believer does not go with an arrogant or aggressive attitude and a purpose of grinding the sinner and punishing him. No not at all! He must go with the purpose to win him over as it is also said in Galatians 6:1, 2: Brothers, if someone is caught in a sin, you who are spiritual, should restore him gently. But watch yourself, or you also may be tempted. Carry each others burdens, and you will fulfil the law of Christ. But then if you do go and talk and plead with this wandering brother or sister, but they do not listen and do not repent, you should take one or two fellow believers along and then together, try to restore the wandering believer. If he still does not listen and does not repent, the whole issue should be taken to the elders as the representatives of the church. If the elders have looked into the matter carefully and admonished the sinner and prayed for him but he still does not repent, he must be excluded from partaking in the sacraments. This is done in order that the covenant of God is not profaned and his wrath kindled against the whole congregation. By ministering the keys of the kingdom in such a way the church proclaims that the sacraments are only ministered to believers. When someone does not behave himself as a believer, he is not allowed to share in the ministering of the sacraments.

The principle of the priesthood of all believers was strongly pursued by the Pietists of the Post Reformation (Spener, 1964). Perhaps one of the most deliberate and successful uses of the small group principle in church history is the band system of Count Zinzendorf in the middle of the 18th century. The micro communities of Herrnhut combined the aspects of fellowship and sharing, mutual correction and confession, prayer and an urgent sense of mission to send the gospel to the world and bring renewal to Christians. Zinzendorf practiced church renewal through small groups and then send those groups to do worldwide church planting. (Comiskey 2014:142).

Although the division of the Moravian Christians at Herrnhut into smaller groups referred to as 'bands' and eventually 'choirs' began in July 1727. The United Brethren practiced these small group meetings even before arriving at Herrnhut. The bands grew rapidly: in 1732 there were 77 bands, and by 1734 there were 100 .

To implement the principle of the priesthood of all believers, Zinzendorf established choirs (for married men, married women, single ladies, single men, girls, boys and babies) who essentially were lay people pastoring the congregation: men pastoring men, women pastoring women (Hutton 2016).

The dynamic connection between small groups and missions is the lasting legacy of the Moravians. The emphasis on missions helped the groups adapt to culture and different circumstances.

John Wesley not only made it clear that Moravian missionaries were instrumental to his conversion experience, but his implementation of the Methodist societies was also an adaptation of the band and choir system he later learned during his visit to Zinzendorf at Hernhut.

The Methodist societies, according to Wesley (quoted in Snyder 2014), met

in order to pray together, to receive the word of exhortation, and to watch over one another in love, that they might help each other to work out their salvation.

In the small group ministry, there is tremendous encouragement to apply instructions like 1 Peter 4:8-11:

Above all, keep loving one another earnestly, since love covers a multitude of sins. Show hospitality to one another without 
grumbling. As each has received a gift, use it to serve one another, as good stewards of God's varied grace: whoever speaks, as one who speaks oracles of God; whoever serves, as one who serves by the strength that God supplies - in order that in everything God may be glorified through Jesus Christ. To him belong glory and dominion forever and ever. Amen.

With our experience with the implementation of small group ministry in Brazil, we realised that the variety of gifts and talents can best be stimulated in small group ministry, facilitate spiritual growth of individuals and facilitate the emerging of new leaders.

Finally, small group ministry offers the opportunity for a missional response to the world. When Wesley created the Methodist societies, there were three major commitments for a member: to avoid sinfulness at all cost, to regularly attend the ordinances, and as much as possible offer compassion to the poor and those in need. For the last purpose, all members of the classes were stimulated to contribute 'a penny a week and shilling a quarter' (Snyder 2014). This led the Methodist societies to see the city as their parish and they rushed towards the poor, the orphans, the widows and prisoners. Wesley belonged to the high class of his time but was driven by compassion which for him was the heart of the gospel. He used to say, Christianism without compassion is only formality, a dry religion, like a rope of sand (Stuart 2008).

The same principle of compassion started to spontaneously emerge through the small group ministry of the four churches in Brazil. In the Presbyterian Church of Macaé, the small groups were challenged to look at the city as their field. One of our groups invited some doctors to give a whole day of free consultations in a poor region of the city. To be sure that everybody would know of the doctors, they took a car with a loudspeaker and went to the streets of the favela [slum] and shouted the following message: 'The hands of Christ is in your place today, take your children, your grandfathers and go to the central square, the doctors will help you today.' Hundreds of children and old men and women went for free consultations, while the members of the small groups prayed and shared the gospel with those who came - ordinary people, doing ordinary things with extraordinary results.

A remarkable missional response was given by the Presbyterian Church of Manaus. In 1990 they began to evangelise the ribeirinhos with a boat, which I personally came to know on one occasion. In doing this, the church came to realise the huge needs the ribeirinhos had: medical assistance, orthodontical assistance, basic sanitation, basic nutrition, child education and many others. Challenged by this, with a partnership with the World Vision in 1992, they built a 20 metre boat equipped with ambulatory rooms, to bring doctors, dentists, and social assistants to attend to the needs of the ribeirinhos in several rivers of Amazonia. Today, they have 10 boats ( 2 of them are hospital boats) travelling 30 times a year, attending to 10000 persons per year. Another boat was prepared, especially to bring missionaries from all over the world for short evangelisation projects, helping around 10000 persons per year. Dozens of churches have been planted resulting from the missional response of the Presbyterian Church of Manaus, as an incontestable proof that compassion must come together with the preaching of the gospel.

\section{Possible role of small group ministry of the revitalisation of Iglesia Presbiteriana do Brasil congregations to strengthen their missional outreach}

Can small group ministry be an instrument to revitalise the IPB? The Presbyterian Church of Manaus is the largest in Brazil, and they consider the small group ministry as the main strategy for their growth. Only during the last year, more the 350 new members were added to the central church in Manaus. Unfortunately, up to today the IPB as denomination has not realised the tremendous opportunity that small group ministry offers to our congregations. For many years, IPB has taken resolutions in the general assembly forbidding several existing models of small group ministries in Brazil to be adopted by our congregations. We all agree that no model is perfect, and any model has its virtues and limitations, however, the challenge remains IPB must find a way to present to our communities an acceptable model that can inspire each local church to establish small group ministries.

In general, a very common concern of pastors and presbyters in IPB is whether this structure could become a threat to the traditional societies: SAF, UPH, UMP, UPA (women, men, youth and teenagers). In practice, none of the four churches, which implemented small group ministries experienced such threats. There is nothing in the small group ministry that could become a barrier for any other ministry or society in IPB. In fact, it could improve the participation or even give new directions to these old structures.

\section{Suggestions to the Iglesia Presbiteriana do Brasil and other denominations}

After 21 of years working with the small groups, I came to the conclusion that it is possible to offer a very simple model that fits in reformed and Presbyterian traditions and ecclesiology. Firstly, there should be no rush - it begins with the change of vision, not structures. Life in community is not a matter of a programme, but it is a relationship; it is not a matter of what to do or not to do, but a matter of being, a matter of loving one another.

I would suggest beginning with a core group, with the key leadership of the church; if possible one with elders and deacons who could be the first generation of small group leaders. The pastor must become the pattern, the living model, in such a way that he could say like the apostle Paul: 'Follow my example, as I follow the example of Christ' (NIV 1 Cor 11.1). He must be a living model of sanctification, a living model of a true witness, a living model of a Bible 
reader, of an intercessor, a living model of a friend, a living model of a disciple of Christ, of a soul winner, a living model of the compassion of Christ for the lost, for the poor, for the children, for the prisoners, for the hungry, a living model of a balanced and healthy family, a humble sinner to confess his own limitations and weakness, a sincere imitator of Christ.

God does not use programmes, but people. The agenda of the small group could be very simple: a warm welcome to the visitors, a praise time that could be in a simple way, even a Capella, a prayer time for one another, a time to apply the Word and a final time to pray for friends and neighbours. It is very important that all teaching must come from the pastor to prevent wrong doctrines being spread. The formation and training of new leaders cannot be despised in any way. It is the pastor's responsibility to prepare them for the task.

Supervision is the key factor that keeps the whole system working. The pastor will be the supervisor of elders and deacons, or even of the first generation of leaders, because they again will be the supervisors of the next generation of leaders. Two things must not be forgotten and constantly be emphasised: the discipleship of the newcomers and the missional response of the group. The discipleship grants the nutrition and maturity of those who have come to Christ by the evangelisation of the group. But each group must be challenged to find its mission field. God has a purpose for each small group and they could make a covenant to find their missional vocation and do what is possible to accomplish the task: to bring the love of Christ to the people. I think in terms of major instructions and giving liberty for each church to create her own arrangements.

\section{Final conclusion}

The history of the church growth of four Presbyterian churches, in four different places, with a common concern, how to revitalise the church, can be summarised as follows: The pastors of these churches had no idea of all that could come to their communities with the small group ministry. However, those pastors and their councils had no fear to fail, to begin again, but in fact, although we made some mistakes, we had some failures, we faced criticism from every side, we followed the vision: to see our communities in a deep commitment to the kingdom of God. The four churches had the same feeling - we were thankful for what God had done for us, but it was not good enough. There were many others to bring to Christ, many others to help, to serve, many others to whom compassion and love must be offered. There was no need to leave the denomination, our councils, our confession of faith, our ecclesiology, our precious tradition. We could be Presbyterian churches as any other in our region, but with a new spirit, a new vision, a new challenge, a missional vocation. These four churches may be an inspiration for IPB and other reformed churches, not as a model, but inspiration to search a new way to be relevant to our time and place.

\section{Acknowledgements Competing interests}

The authors declare that they have no financial or personal relationship(s) which may have inappropriately influenced them in writing this article.

\section{Authors' contributions}

P.J.B. was the project leader, and E.B.N. provided empirical data from personal experiences (autoethnographical qualitative research) and received responses on questionaires.

\section{References}

Banks, R., 1980, Paul's idea of community: The early house churches in their historical setting, Exeter, Paternoster

Barr, S.M., 2016, 'Biblical principles of small group ministry', Thesis project submitted to the Faculty of Liberty, University School of Divinity in candidacy for the degree of Doctor of Ministry, viewed 07 April 2018, from http://digitalcommons.liberty. edu/cgi/viewcontent.cgi?article=2226\&context=doctoral

Brazilian Institute of Geography and Statistics (IBGE), 2010, Census 2010, viewed 10 Sept. 2018, from https://censo2010.ibge.gov.. r $/$ /noticias-censo?id=3\&idnoticia= 2170\&view=noticia

Bucer, M., 2009, Concerning the true care of souls, transl. P. Beale, Banner of Truth Trust, Edinburgh.

Buys, P.J., 2012, Theological presepctives on church revitalization, Lecture presented at Mukhanyo Theological College, (Unpublished).

Buys, P.J., 2013, Applying church discipline in Christ's way and gain missional strength, Lecture presented at Mukhanyo Theological College. (Unpublished).

Castellanos, C., 2002, Successful leadership through the government of twelve, Jubilee Christian Center, San Jose, CA.

Castellanos, C., 2013, Liderazgo y visión, BookBaby, Bogota.

Castellanos, C., 2015, Victory through the blood, BookBaby, Bogota.

Centro Presbiteriano de Pós-Graduação Andrew Jumper (CPAJ), 2018, Especialização em Revitalização e Multiplicação de Igrejas (RMI), viewed 5 October 2018, from http://cpaj.mackenzie.br/programas-cursos/especializacao-rmi/

Comiskey, 2014, 2000 years of small groups, loc. 1084-1085, Kindle.

Ellis, C. \& Bochner, A.P., 2000, 'Autoethnography, personal narrative, reflexivity: Researcher as subject', in Denzin \& Lincoln (eds.), Sage Publications, Thousand Oaks, California.

Huber, A., 2012a, Discipulado um a um: Crescimento com qualidade, Premius, Fortaleza.

Huber, A., 2012b, Ide e fazei discípulos: Fundamentos práticos para ser e fazer discípulos de Jesus, Premius, Fortaleza.

Huber, A., 2016, Treinamento de líderes de células, Editora Leal, Fortaleza.

Hutton, J.E., 2016, The history of the Moravians, Lulu Press, Morrisville, NC.

IBGE, see Brazilian Institute of Geography and Statistics

Keller, T.J., 2012, Center church: Doing balanced gospel-centered ministry in your city, Zondervan, Grand Rapids, MI.

Lessa, V.T., 1938, Annaes da $1^{a}$ Egreja Presbyteriana de São Paulo (1863-1903), Primeira Igreja Presbyteriana Independente de São Paulo, São Paulo.

Mariano, R., 2013, Mudanças no campo religioso brasileiro no censo 2010, viewed 01 August 2018, from http://seer.ufrgs.br/index.php/debatesdoner/article/view/ $43696 / 27488$

Neighbour, R.W., 1992, The shepherd's guidebook: A leader's guide for the cell group church, Achievers Resources Centre, Houston, TX.

Neighbour, R.W., 2000, Where do we go from here?: A guidebook for the cell group church, Touch Outreach Ministries, Houston, TX.

Neighbour, R.W., 2008, Christ's basic bodies: Embracing God's presence, power, and purposes in holistic small group life: Cell groups, home groups, life groups, and biblical communities, Touch Publications, Houston, TX.

Smith, K.G., 2016, Writing and research: A guide for theological students, Langham Press, Cambridge.

Snyder, H.A., 1996, The radical Wesley and patterns for church renewal, Wipf \& Stock Publishers, Eugene, OR.

Snyder, H.A., 2014, The radical Wesley, Seedbed Publishing, Franklin.

Spener, P.H., 1964, Pia Desideria, transl. T.G. Tappert, Fortress Press, Philadelphia, PA.

Stuart, J., 2008, The John Wesley Code: Finding a faith that matters, Philip Garside Publishing, Wellington, New Zealand.

Vogler, W., 1982, 'Die Bedeutung der urchristlichen Hausgemeinden fur die ausbreiting des Evangeliums', Theologische Literaturzeitung 107(11), 875-794.

Wright, D.F., 1994, Martin Bucer: Reforming church and community, Cambridge University Press, Cambridge. 